\title{
Remobilization of zinc in sediments by mangrove and its associated species in Blanakan River, West Java, Indonesia
}

\author{
NOVERITA DIAN TAKARINA ${ }^{\text {" }}$ \\ Department of Biology, Faculty of Mathematics and Natural Sciences, Universitas Indonesia. Pondok Cina, Beji, Depok16404, West Java, Indonesia. \\ Tel.: +62-21-7270163, 78849009, Fax.: +62-21-78849010, `email: noverita.dian@ sci.ui.ac.id.
}

Manuscript received: 4 March 2020. Revision accepted: 30 March 2020.

\begin{abstract}
Takarina ND. 2020. Remobilization of zinc in sediments by mangrove and its associated species in Blanakan River, West Java, Indonesia. Biodiversitas 21: 1743-1748. The biodiversity of mangrove and associated species have contribution to remove contaminants from aquatic environment, for example, river. This work aims to study the effects of mangrove and associated species in absorbing zinc $(\mathrm{Zn})$ from water and sediment and remobilizing it into stems. The work was conducted by sampling mangroves, associated species, sediment and water along 9 stations in riparian of Blanakan River, West Java. The stems of mangrove and associated species, water and sediments were analyzed for $\mathrm{Zn}$ content using AAS. The biodiversity was evaluated using Shannon-Wiener index (H'). The bioremobilization potential was calculated using Bioconcentration Factor (BCF). There were 3 true mangrove species (i.e. Rhizophora mucronata, Avicennia marina, and Sonneratia caseolaris) and 3 mangrove associate species (i.e. Colocasia esculenta, Ipomoea aquatica, and Wedelia biflora). The H' was ranging from 0.5 to 0.7 . We found that the riparian with high species richness and biodiversity has less $\mathrm{Zn}$ contents both in water and sediments, while the riparian that has low species diversity has high $\mathrm{Zn}$ in water and sediments. All the mangrove and associated species have stored $\mathrm{Zn}$ in their stems with the most effective species in remobilizing $\mathrm{Zn}$ from water and sediment were $C$. esculenta, S. caseolaris, and $R$. mucronata. The contamination of $\mathrm{Zn}$ in aquatic ecosystem can be managed and reduced by increasing mangrove and associated species diversity and planting species that effective in remobilization of contaminants from environment.
\end{abstract}

Keywords: Associated species, mangrove, bioconcentration factor, $\mathrm{Zn}$

\section{INTRODUCTION}

Mangrove forest consists of several mangrove species growing and experiencing submerged bases at the area between land and sea interface (Kathiresan et al. 2001; Horstman et al. 2012; Djamaluddin 2018). Mangrove can expand throughout tropical coastlines covering vast areas and plays significant ecological role in stabilizing and maintaining the balance within marine habitats and coastal landscape (Alongi 2002). Mangrove also functions as buffer zone between the estuary and coast and the terrestrial and anthropogenic areas, enriched with metallic elements (Linneweber 2002; Sukardjo 2004; Santos et al. 2014; Chaudhuri et al. 2019).

Nearly 33 mangrove species and 22 associated species (Ghosh et al. 2012) are widespread in worldwide including Rhizophora sp., Avicennia sp. which are known as cosmopolitan species that dominate several rivers and coastal habitats in Asia (India, Indonesia, Sri Lanka), Australia, South America (Brazil) and Eastern Africa. Such plant diversity is known to have correlation with the heavy metal availability in ecosystem (Hernández and Pastor 2008). In those habitats, mangroves have capability to remobilize heavy metal contents from surrounding environment including water and sediments. This remobilization is measured as Bioconcentration Factor (BCF). Many literature have discussed the BCF of mangrove species. Study conducted in mangrove ecosystem in Persian gulf recorded the BCF of Zinc (Zn) of sediment-to-stem for Avicennia sp. was 0.49 (Einollahipeer et al. 2013). While, for mangrove associates, the $\mathrm{Zn}$ sedimentto-stem BCF of Colocasia esculenta was ranging from 334 to 625 (Chayapan et al. 2015). In associated Pluchea indica and Sesuvium portulacastrum, the $\mathrm{Zn}$ ranges were 9-28 $\mathrm{mg} / \mathrm{kg}$ and $6-19 \mathrm{mg} / \mathrm{kg}$, respectively. The BCF of $\mathrm{Cu}$ in Pluchea indica was $>1$ (Soraya et al. 2019). Despite considered as heavy metal, $\mathrm{Zn}$ is one of the essential micronutrients for plant growth and nontoxic (Appenroth 2010; Almahasheer et al. 2018). However, the $\mathrm{Zn}$ can be toxic for plant if the $\mathrm{Zn}$ exceeds the plant toxicity threshold which is $300-600 \mathrm{mg} / \mathrm{kg}$ (Long et al. 2003).

Blanakan River in West Java has mangrove and associated species along its riparian zone. The common mangroves found in riparian of Blanakan include Avicennia sp. and Rhizophora sp. (Siarudin and Rachman 2008). Meanwhile, the mangrove associates in Blanakan consisted of 17 species from 11 families (Khorimatun et al. 2019). However, Blanakan River is also experiencing anthropogenic influences and waste disposal. The settlements near Blanakan can contribute pollutants to river such as heavy metals as well. Recently, the data regarding the potential of mangroves and associated species in Blanakan River in remobilizing the metals from water and sediments are still limited. Most literature is discussing the mangroves and heavy metals solely in river in Jakarta. Respectively, this study aims to investigate the BCF value of mangroves and associated species stems in remobilizing $\mathrm{Zn}$ from water and sediments of Blanakan River. 


\section{MATERIALS AND METHODS}

\section{Study area and period}

Blanakan River is located in Subang District, West Java Province, Indonesia (Figure 1). The width of Blanakan river is varied from $60 \mathrm{~m}$ near the river mouth to $11 \mathrm{~m}$ in the upstream. Data collection was performed twice in April and June 2019 during transition season from rainy to dry in Blanakan River. The study periods were 2 months.

\section{Procedures}

Mangroves and associated species sampling

Data collection was conducted using purposive sampling method by establishing nine observation stations. The stations were from upstream at geocoordinate of S $6^{\circ} 16^{\prime} 38^{\prime \prime}$ and $\mathrm{E}$ $107^{\circ} 39^{\prime} 35^{\prime \prime}$ (Station 1) to downstream (river mouth) at $\mathrm{S}$ $6^{\circ} 14^{\prime} 24^{\prime \prime}$ and S 107 $40^{\prime} 02^{\prime \prime}$ (Station 9) (Figure 1). In the upstream, Stations 1-3 were surrounded by settlements and paddy field, Stations 4-6 were transition area for paddy field to fish pond and Stations 7-9 were dominated by fish pond and revegated mangrove. At each observation station, we made $10 \mathrm{~m}$ x $10 \mathrm{~m}$ sampling plot. The sampling replications were 3 in each observation station with the numbers of total sampling plots were 27 for 9 observation stations.

True mangroves and mangrove associates were recorded in nine stations across the river. The identification book was used to identify the mangroves and associated species (Noor et al. 1999).
Heavy metals (Zn) sampling and analysis for stems, water, and sediment in river

In the river, water sample was collected and stored in polyethylene bottle and kept in cooler box to be transported to the Environment Laboratory, Sekolah Ilmu Lingkungan, Universitas Indonesia. In the laboratory, the water sample was analyzed using Atomic Absorption Spectrophotometer (AAS) Perkin Elmer Analyst 800 to obtain the $\mathrm{Zn}$ values.

River sediment at surface layer $(5 \mathrm{~cm})$ was collected using Ekman grab sampler. The collected sediments were kept in the plastic bag and cooler box to be transported to the laboratory. In the laboratory, the sediment sample was analyzed using AAS to obtain the $\mathrm{Zn}$ values (Takarina and Pin 2017).

Stems of true mangroves and mangrove associates were cleaned and cut into small pieces. The stems were dried in the oven at $80{ }^{\circ} \mathrm{C}$. Then, $0.5 \mathrm{~g}$ of dry stems were digested using the aqua regia (HCL: $\mathrm{HNO}_{3}=3: 1$ ) and heated until achieving a volume of $1 \mathrm{ml}$. Double distilled water $\mathrm{ddH}_{2} \mathrm{O}$ was then added to each stem sample and samples were filtered using Whatman paper No. 2 until a volume of 25 $\mathrm{ml}$ was obtained. The resulting filtrate was submitted to AAS for $\mathrm{Zn}$ analysis. The stem preparations of mangrove and associated species were according to Einollahipeer et al. (2013) and Kannan et al. (2016).

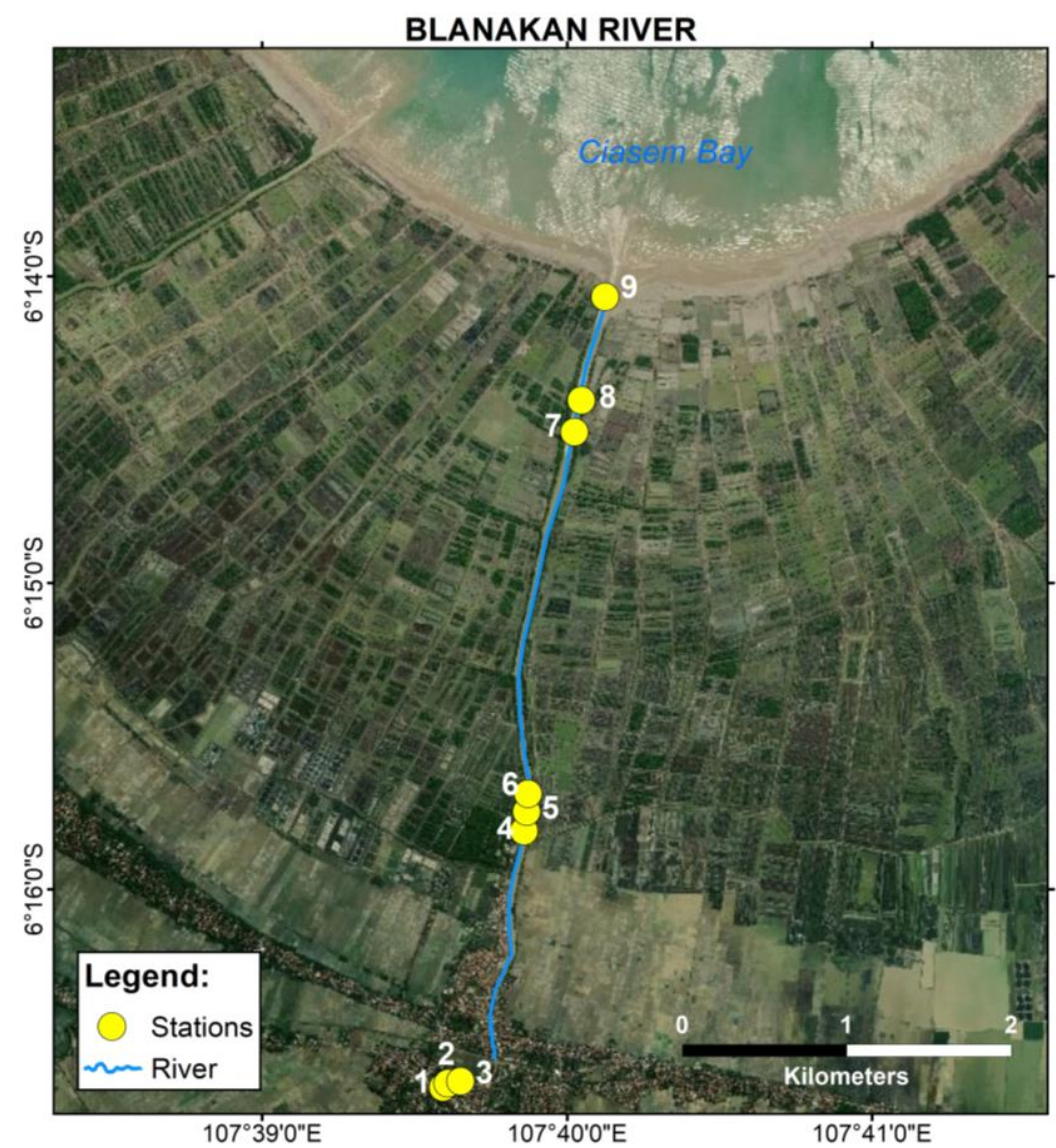

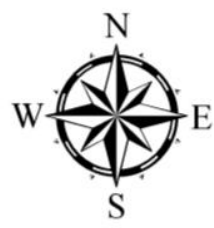

WEST JAVA PROVINCE

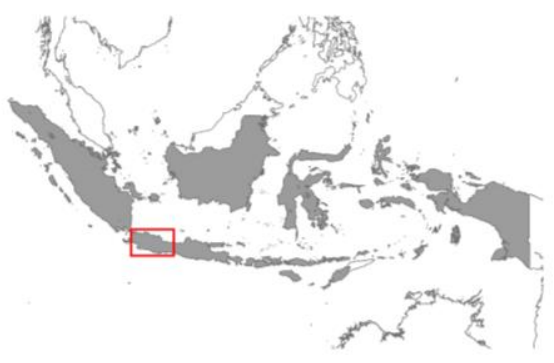

SUBANG DISTRICT

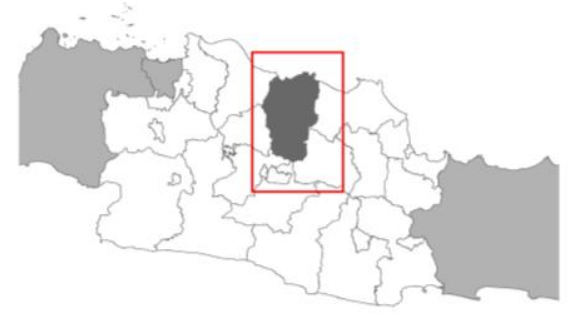

Figure 1. Location of Blanakan River, Subang District, West Java Province, Indonesia indicating the sampling sites 
Water quality parameter data sampling

Sampling of water quality parameter was done in situ. The parameters including dissolved oxygen (DO), $\mathrm{pH}$, salinity, temperature, and turbidity. DO and temperature were measured using $\mathrm{DO}$ meter, $\mathrm{pH}$ using $\mathrm{pH}$ meter, salinity using refractometer and turbidity using turbidity meter (Takarina and Pin 2017).

\section{Data analysis}

Water-sediment-to-stem tissue was defined as Bioconcentration Factor (BCF) and calculated using equation as follow:

$$
\mathrm{BCF}=\frac{\mathrm{Cm}}{\mathrm{Cw} / \mathrm{s}}
$$

Where: $\mathrm{Cm}$ is the concentration of heavy metals in stems of mangroves and associated species and $\mathrm{Cw} / \mathrm{s}$ is the concentration of heavy metals in water or sediment (Takarina and Pin 2017).

Biodiversity index ( $\mathrm{H}^{\prime} /$ Shannon-Wiener diversity index) was calculated using following equation:

$$
\mathrm{H}^{0}=-\sum_{\mathrm{i}=1}^{5} \text { piln(pi) }
$$

Where: $H^{\prime}=$ biodiversity index, $\mathrm{pi}=$ the proportion of individuals of the $\mathrm{i}^{\text {th }}$ species, $\ln =$ the natural $\log$ arithm, $\mathrm{s}=$ the number of species in the community.

\section{Dendrogram analysis}

The similarity between mangrove species and associated species were calculated using dendrogram. The data used to determine the distance of similarity are the $\mathrm{Zn}$ Bioconcentration Factor. The dendrogram analysis used is hierarchical clustering by corresponding analyses. The software used to generate the dendrogram was NCSS 2020 Data Analysis.

\section{RESULTS AND DISCUSSION}

\section{Mangroves and associated species biodiversity}

The mangroves in the studied area consisted of 3 families with 3 species and the associated species consisted of 3 families and 3 species as well (Table 1).
The upstream riparian in Station 1 had high biodiversity of associated species (Figure 2). While, the $\mathrm{H}^{\prime}$ value for true mangroves was increasing from middle parts of riparian towards river mouth. The downstream riparian of Blanakan had high mangrove biodiversity especially in Station 6. Station 2 in the upstream was the only location that had the lowest biodiversity. There was neither mangrove nor associated species found in here.

\section{Correlation of mangrove biodiversity and $\mathrm{Zn}$ in sediments and water}

The $\mathrm{Zn}$ in sediments of Blanakan River ranged from 73.42 to $118.33 \mathrm{mg} / \mathrm{kg}$ (Figure 3.A). While the $\mathrm{Zn}$ range in water was $0.40-2.13 \mathrm{mg} / \mathrm{L}$ (Figure 3.B). The sediments in Station 2 has the highest $\mathrm{Zn}(118.33 \mathrm{mg} / \mathrm{kg})$ compared to other stations. This condition is likely related to the absence of mangrove in this station.

Correspondingly, the biodiversity of mangroves and associated species at Station 2 was the lowest. Figure 4 confirms that there is a negative correlation $(\mathrm{r}=0.848)$ between biodiversity and the $\mathrm{Zn}$ in sediments. The riparian with high biodiversity has less $\mathrm{Zn}$ contents in sediments. While, the riparian that has low species diversity has high $\mathrm{Zn}$ in sediments.

\section{The effectiveness of mangroves and associated species in $\mathrm{Zn}$ remobilization}

Based on the $\mathrm{Zn}$ storage in stems of mangroves and associated species, the $\mathrm{Zn}$ remobilization can be calculated. The Bioconcentration Factor (BCF) was used to calculate the effectiveness of water-to-stems (Figure 5.A) and sediment to stems (Figure 5.B). For associated species, $C$. esculenta had high BCF values and was more effective in remobilizing $\mathrm{Zn}$ from water and sediments. For true mangrove species, the BCF of water-to-stems was $S$. caseolaris $>R$. mucronata $>$ A. marina. While the BCF of sediments-to-stems was $S$. caseolaris $>R$. mucronata $>A$. marina. Based on dendrogram (Figure 6) developed upon the similarity on BCF, the associated species $C$. esculenta had more similarity to mangrove species $S$. caseolaris, $R$. mucronata, and A. marina. Between true mangroves, $S$. caseolaris and $R$. mucronata have more similarities.

Table 1. Mangroves and associated species in riparian of Blanakan river, West Java, Indonesia

\begin{tabular}{lllll}
\hline Type & Family & Species & Stations & Land use \\
\hline Associates & Asteraceae & Wedelia biflora & 1 & Settlement + paddy field \\
& Araceae & Colocasia esculenta & 1 & Settlement + paddy field \\
& Convolvulaceae & Ipomoea aquatica & 1 & Settlement + paddy field \\
Mangrove & Sonneratiaceae & Sonneratia caseolaris & 3 & Settlement + paddy field \\
& & & 4,6 & Transition \\
& Rhizophoraceae & Rhizophora mucronata & 4,6 & Transition \\
& & & $7,8,9$ & Fish pond + mangrove \\
& Acanthaceae & Avicennia marina & 5 & Transition \\
& & & 7,8 & Fish pond + mangrove \\
\hline
\end{tabular}




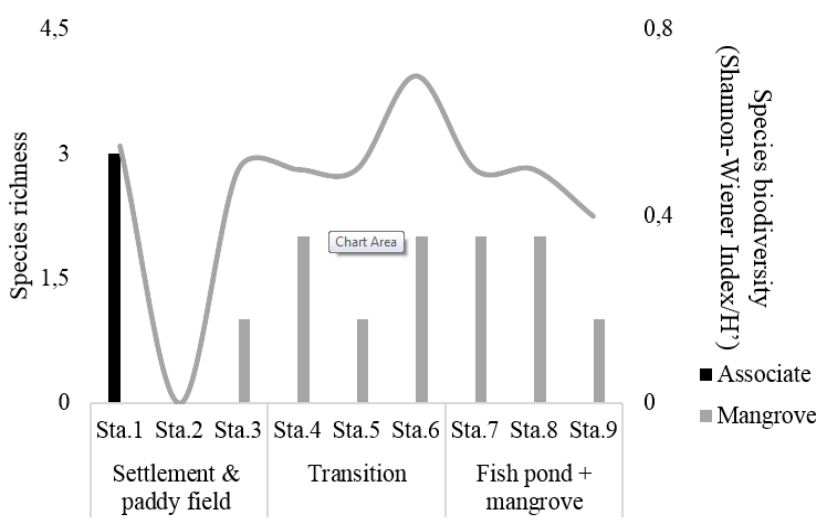

Figure 2. Trend in species richness and biodiversity index (Shannon-Wiener Index/H') of mangroves and associated species in riparian of Blanakan River, West Java

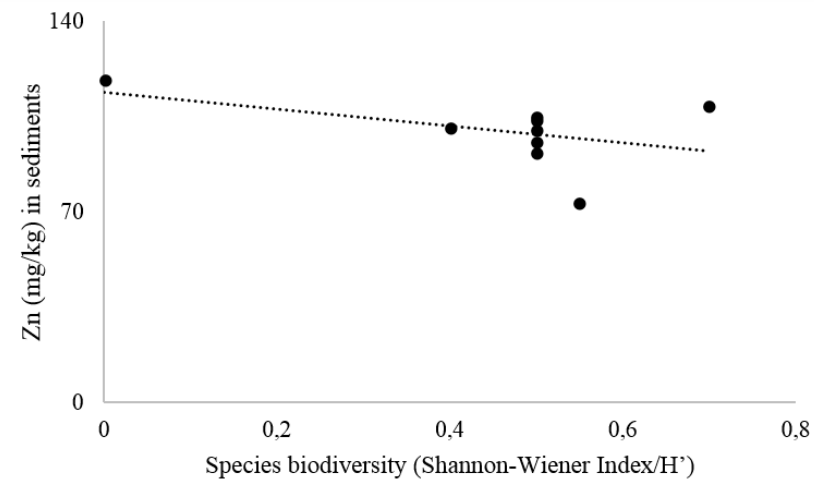

Figure 4. Correlation $(\mathrm{r}=0.848)$ of mangroves and associated species biodiversity (Shannon-Wiener Index/H') values with $\mathrm{Zn}$ $(\mathrm{mg} / \mathrm{kg})$ in sediments in riparian of Blanakan River, West Java, Indonesia
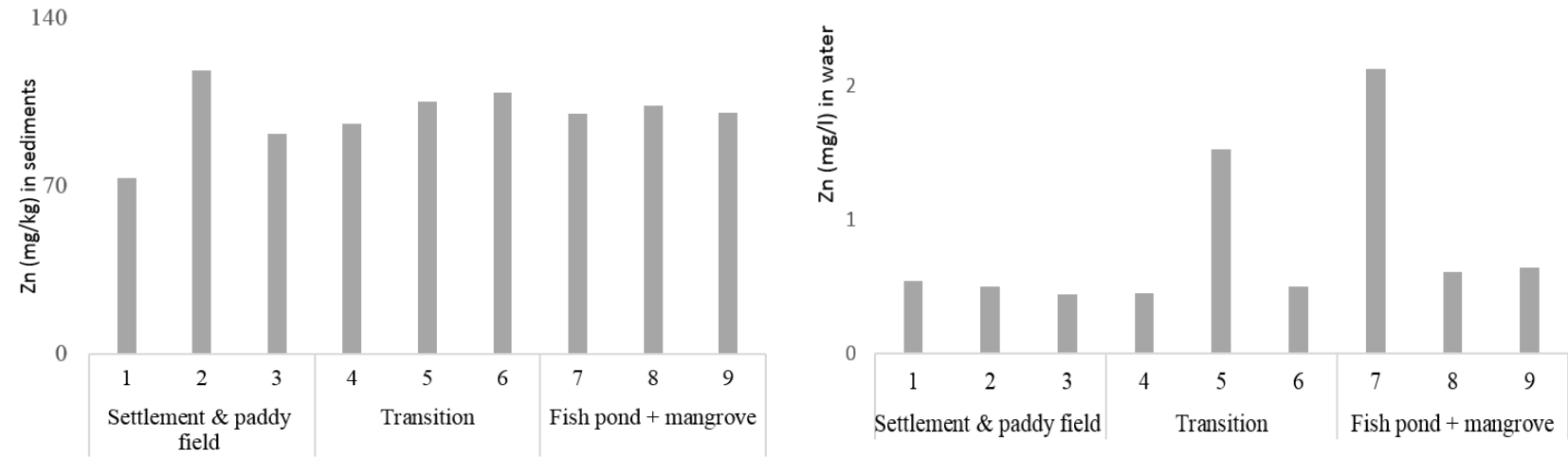

Figure 3. Zn values $(\mathrm{mg} / \mathrm{kg}$ ) in sediments $(l e f t)$ and water $(r i g h t)$ of riparian of Blanakan River, West Java, Indonesia
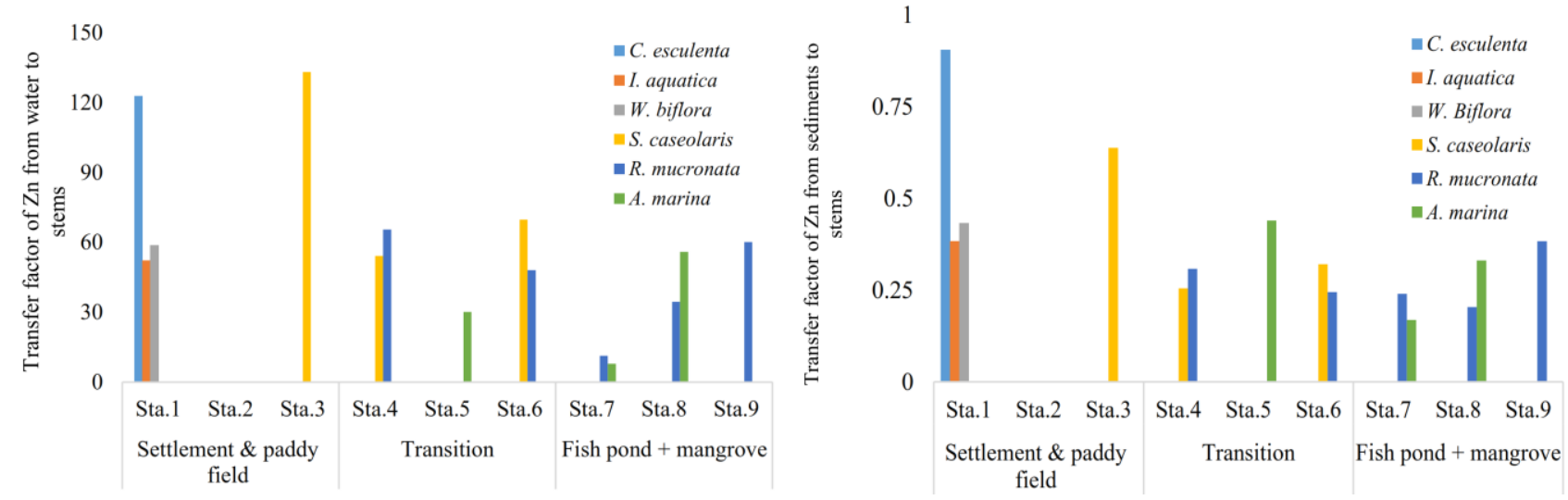

Figure 5. Bioconcentration factor of $\mathrm{Zn}$ from water-to-stems of mangroves and associated species (left); and from sediment-to-stems of mangroves and associated species (right), in riparian of Blanakan River, West Java, Indonesia 
Table 2. Water quality parameter data in riparian of Blanakan River, West Java, Indonesia

\begin{tabular}{lccccccccc}
\hline \multirow{2}{*}{ Parameters } & \multicolumn{3}{c}{ Settlement and paddy field } & \multicolumn{2}{c}{ Transition } & \multicolumn{2}{c}{ Fish pond and mangrove } \\
\cline { 2 - 9 } & Sta.1 & Sta. 2 & Sta. 3 & Sta. 4 & Sta.5 & Sta. 6 & Sta. 7 & Sta. 8 & Sta.9 \\
\hline Salinity & 4 & 4 & 4 & 5 & 6 & 7 & 10 & 10 & 10 \\
Turbidity (NTU) & 203 & 233 & 136 & 110 & 141 & 129 & 91 & 96 & 203 \\
pH & 7.6 & 7.7 & 7.66 & 7.37 & 7.4 & 7.3 & 7.5 & 7.4 & 7.6 \\
Temperature $\left({ }^{\circ} \mathrm{C}\right)$ & 29 & 26 & 25 & 27 & 27 & 27 & 27 & 29 & 29 \\
Dissolved oxygen (mg/L) & 6.9 & 7 & 6.7 & 5.8 & 3.6 & 5.5 & 6.9 & 4.4 & 6.9 \\
\hline
\end{tabular}

Table 3. Comparison of $\mathrm{Zn}(\mathrm{mg} / \mathrm{kg})$ detected in stems of mangroves and associated species from Blanakan River with the permissible level of international agencies (WHO: World Health Organization, CEQG: Canadian Environmental Quality Guidelines)

\begin{tabular}{lccccccc}
\hline \multirow{2}{*}{ Metal } & Permissible value & Permissible value & \multicolumn{3}{c}{ True mangroves } & \multicolumn{3}{c}{ Associated species } \\
\cline { 4 - 8 } & in plant by WHO & in plant by CEQG & Sc & Rm & Am & Ce & Ia \\
\hline Zn & 0.6 & 124 & 39.31 & 27.97 & 32.43 & 66.35 & 28.15 \\
\hline
\end{tabular}

Note: Sc: S. caseolaris, Rm: R. mucronata, Am: A. marina, Ce: C. esculenta, Ia: I. aquatica, Wb: W. Biflora

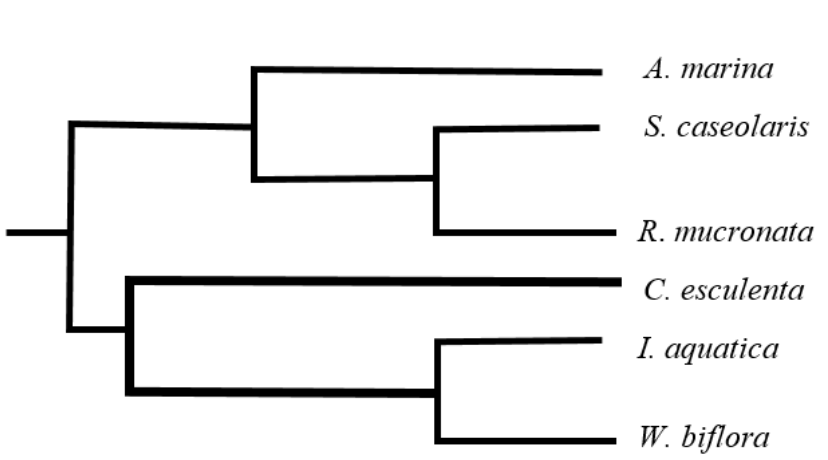

Figure 6. The dendrogram of mangroves and associated species based on similarity in $\mathrm{Zn}$ remobilization

\section{Discussion}

The associated species like Colocasia esculenta and Wedelia biflora were common in settlement and paddy fields in the upstream. While, $R$. mucronata was a mangrove species that more common compared to $S$. caseolaris and A. marina. S. caseolaris was a species that inhabit the upstream closed to associated species. Study in Banyuasin river also found that $S$. caseolaris was a common species that prefer upstream part (Winata et al. 2017). Most mangrove species like $R$. mucronata and $A$. marina were more common in the downstream riparian close to the river mouth. The $\mathrm{H}^{\prime}$ value ranges in here were 0.4-0.7 and it was comparable with $\mathrm{H}^{\prime}$ values from other results. In Banyuasin river, the $\mathrm{H}^{\prime}$ was $0.7-0.8$ (Winata et al. 2017). This indicates that the diversity in Blanakan river is quite good.

There are obvious patterns of mangrove and associated species biodiversity between upstream and downstream. This study found that the mangrove associates had dominated the upstream and the true mangroves had dominated the downstream. Our findings are comparable to

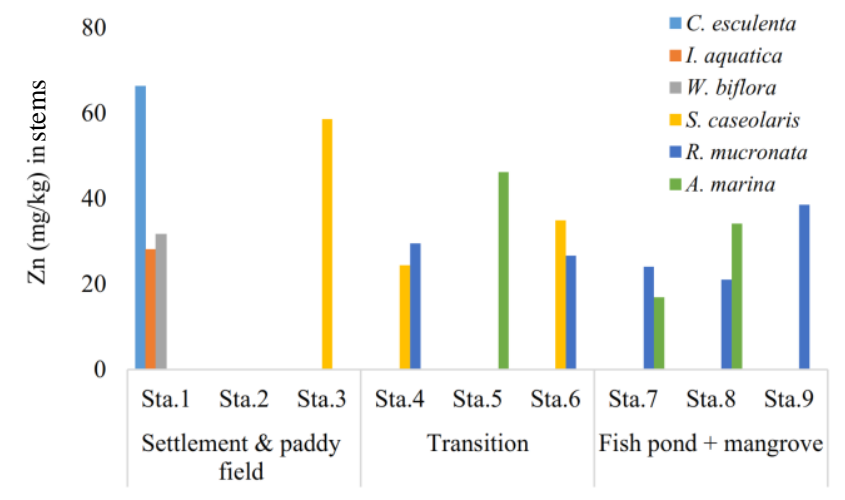

Figure 7. $\mathrm{Zn}$ values $(\mathrm{mg} / \mathrm{kg})$ in stems of mangroves and associated species in riparian of Blanakan River, West Java, Indonesia

results from other studies. In Sundarban (Sarker et al. 2019), the pattern was related to the salinity gradient in downstream-upstream in shaping spatial distributions of all aspects of biodiversity. In our study, the downstream and intermediate-stream areas were more suitable for mangrove species. While the upstream was more suitable for associated species, which are known as less tolerant species to salinity (Naik and Dhab, 2018). Our water quality parameter data in Table 2 confirm that salinity was higher in downstream where mangrove species were more diverse.

In Station 2, vegetation was absent and had the highest $\mathrm{Zn}$ in the sediment. It has been reported that the barren land and deforested area will have accumulated $\mathrm{Zn}$ mainly in sediment. The high level of heavy metals is related to erosion process. In deforested area where vegetation cover is low, the eroded soils from terrestrial will be transported and accumulated in the river bank. The transported soils contain heavy metals and will increase the metal contents in areas where vegetation biodiversity is low (Khaleghi 2017). High turbidity up to 233 NTU (Table 2) was the evidence of erosions and this turbidity level inhibited plant 
seedlings to grow and as a result, there were no plants growing in here.

The correlation of high mangrove biodiversity with the low $\mathrm{Zn}$ in sediment is related to the ability of mangrove to absorb $\mathrm{Zn}$ from sediment and store it in the stems. All the mangroves and mangrove associates inhabiting the riparian of Blanakan River have ability to absorb $\mathrm{Zn}$ from their surrounding aquatic environments (Figure 7). For the associated species, the stems of $C$. esculenta absorbed more $\mathrm{Zn}$ compare to other species. While, for the true mangrove species, the $\mathrm{Zn}$ storage in stems was $S$. caseolaris $>A$. marina $>$ R. mucronata.

In this study, all $\mathrm{Zn}$ in stems of mangroves and associated species were below the permissible level of Canadian Environmental Quality Guidelines (CEQG) (Table 3). However, the $\mathrm{Zn}$ was several folds higher than the WHO (World Health Organization) permissible level in plant (Ogundele et al. 2015). Hence, this result informs that the $\mathrm{Zn}$ contamination in Blanakan River may require health risk attention and assessment.

The biodiversity of riparian in the form of true mangroves and mangrove associates has value not only in the term of gene pool but also functionality. Those mangroves and associated species are complementing each other in stabilizing the heavy metal contents in riparian landscape. In this study, it was confirmed that the stems of associated species $C$. esculenta had $\mathrm{Zn}$ contents higher than true mangroves $S$. caseolaris, A. marina, and $R$. mucronata. These trends of showing the ability of associated species in absorbing heavy metals are comparable with findings from other locations. In India, high concentration of lead and zinc were found to be accumulated in the mangrove species and associated species. The $\mathrm{Zn}$ content in stems of associated species Suaeda nudiflora have exceeded the $\mathrm{Zn}$ in A. marina (Kannan et al. 2016). In Kerala coast, 5 associated species have been reported for their considerable amount of $\mathrm{Zn}$ contents in stems. Those observed mangrove associates were Vitis vitiginia, Cerbera odollam, Premna serratifolia, Barringtonia racemosa and Acrostichum aureum. The recorded $\mathrm{Zn}$ absorbed by those associated species were ranging from 153 to $483 \mathrm{mg} / \mathrm{kg}$. This fact confirms the potential of associated species to complement the true mangroves in removing heavy metals in aquatic ecosystems (Badarudeen et al, 2014). The effectiveness of associated mangrove $C$. esculenta to remove metals from environment has been recorded in many literature as well. The BCF of water to stems of C. esculenta is comparable to other results. The $\mathrm{BCF}$ of $C$. esculenta reported was ranging from 48 to 100 (Madera et al. 2015). Then, $C$. esculenta as associated species has shown a good performance to accumulate metals.

The findings of this study confirmed that the $\mathrm{Zn}$ concentration in stems was high in the following order $S$. caseolaris $>A$. marina $>R$. mucronata for true mangroves. While for the associated species the order was $C$. esculenta $>$ W. biflora $>$ I. aquatica. This marks the importance of biodiversity of riparian vegetation that each species has capability to absorb heavy metal. In overall $\mathrm{Zn}$ accumulations in stems, the mangroves species of $S$. caseolaris is best accumulator for true mangroves. While, the $C$. esculenta is promising accumulator for mangrove associates. Riparian of Blanakan River experiences considerable environmental pressures due to the anthropogenic activities like developments and encroachments that degrade the ecosystem. In this degraded situation, there is an immediate need for a potential heavy metal remediator which can remove significant amount of hazardous contaminants from the water and sediments. Correspondingly, the most potent riparian phytostabilizer species are $C$. esculenta, $S$. caseolaris, and $R$. mucronata, towards the effectiveness of its $\mathrm{Zn}$ removal ability which can be efficiently used as in the riparian of Blanakan River.

High concentration of $\mathrm{Zn}$ in plants may cause toxicity. This also observed in mangrove species. However, mangrove species can tolerate heavy metals and avoid phytotoxicity. Rhizophora mucronata is able to survive with such metals, for example, $\mathrm{Pb}$ concentration of 100 $\mathrm{mg} / \mathrm{L}$ with the concentration of mortality (LC50) was at a concentration of $367.58 \mathrm{mg} / \mathrm{L}$ (Hanarisanty and Titah 2019). Other species also exhibit tolerance, for example, Bruguiera gymnorrhiza and Avicennia marina. Those species often exhibit a thick exodermis with high lignification and suberization that function to delay the transport of $\mathrm{Zn}$ into the plants and hence increase the tolerance of plants to heavy metals and reduce the risk of phytotoxicity (Cheng et al. 2014)

To conclude, this work confirms that maintaining biodiversity by combining mangroves and associated species may accomplish water quality requirements and attain metal removals, and most importantly these can be achieved with potentially lower costs. Hence, conserving the biodiversity of riparian can protect the environment for long term.

\section{ACKNOWLEDGEMENTS}

This research is funded by PIT 9 research scheme provided by DRPM UI (Directorate for Research and Community Service of Universitas Indonesia), Depok, Indonesia with contract number NKB0029/UN2.R3.1/HKP.05.00/2019.

\section{REFERENCES}

Almahasheer H, Serrano O, Duarte CM, Irigoien X. 2018. Remobilization of heavy metals by mangrove leaves. Front Mar Sci 5 484: 1-10. DOI: 10.3389/fmars.2018.00484

Alongi DM. 2002. Present state and future of the world's mangrove forests. Environ Conserv 29: 331-349.

Appenproth K-J. 2010. What are "heavy metaks" in plant sciences? Acta Physiologiae Plantarum 32: 615-619.

Balagadde FK, Song H, Ozaki J, Collins CH, Barnet M, Arnold FH, Quake SR, You L. 2008. A synthetic Escherichia coli predator-prey ecosystem. Mol Syst Biol 4: 1-8. DOI: 10.1038/msb.2008.2

Badarudeen A, Sajan K, Srinivas R, Maya K, Padmalal D. 2014. Environmental significance of heavy metals in leaves and stems of Kerala mangroves, SW coast of India. Indian J Geo-Mar Sci 43 (6): 1027-1035 
Chaudhuri P, Chaudhuri S, Ghosh R. 2019. The Role of Mangroves in Coastal and Estuarine Sedimentary Accretion in Southeast Asia. In book: Sedimentation Engineering. IntechOpen, London. DOI: 10.5772/intechopen.85591

Chayapan P, Kruatrachue M, Meetam M, Pokethitiyook P. 2015. Phytoremediation potential of $\mathrm{Cd}$ and $\mathrm{Zn}$ by wetland plants, Colocasia esculenta L. Schott., Cyperus malaccensis Lam., and Typha angustifolia L. grown in hydroponics. J Environ Biol 36: 11791183.

Cheng H, Jiang Z, Liu Y, Ye Z, Wu M, Sun C, Sun F, Fei J, Wang Y. 2014. Metal $(\mathrm{Pb}, \mathrm{Zn}$ and $\mathrm{Cu})$ uptake and tolerance by mangroves in relation to root anatomy and lignification/suberization. Tree Physiol. 34 (6): 646-656. DOI: 10.1093/treephys/tpu04

Djamaluddin R. 2018. The mangrove flora and their physical habitat characteristics in Bunaken National Park, North Sulawesi, Indonesia. Biodiversitas 19: 1303-1312. DOI: 10.13057/biodiv/d190417

Einollahipeer F, Khammar S, Sabaghzadeh A. 2013. A Study on heavy metal concentration in sediment and mangrove (Avicennia marina) tissues in Qeshm Island, Persian Gulf. J Novel Appl Sci 2 (10): 498 504.

Ghosh A, Sarkar NS, Mukherjee S, Naskar KR. 2012. Distribution of mangrove and mangrove associated plants in different blocks and compartments of Sundarbans tiger reserve (str) with special references to their abundance. Proceeding Volumes (Vol. 1 \& Vol. 2) of XVIII Annual Conference of IAAT and International Seminar in the Department of Botany, University of Kalyani, India.

Hanarisanty L, Titah HS 2019. Finding phytotoxicity test of lead to mangrove plants of Rhizophora mucronata. Jurnal Teknik ITS 8 (2): B26-B31. DOI: 10.12962/j23373539.v8i2.49706

Hernández AJ, Pastor J. 2008. Relationship between plant biodiversity and heavy metal bioavailability in grasslands overlying an abandoned mine. Environ Geochem Health 30:127-133. DOI: 10.1007/s10653 008-9150-4

Horstman E, Dohmen-Janssen M, Narra P, van den Berg N-J, Siemerink M, Balke T, Bouma T, Hulscher S. 2012. wave attenuation in mangrove forests; field data obtained in Trang, Thailand. In: Lynett PJ, Smith JM (eds.). Proceedings of the 33rd International Conference. Coastal Engineering Proceedings, 1 (33). Santander, Spain, 1-6 July 2012.

Kannan N, Thirunavukkarasu N, Suresh A, Rajagopal K. 2016. Analysis of heavy metals accumulation in mangroves and associated mangroves species of Ennore mangrove ecosystem, East Coast India. $\begin{array}{llllll}\text { Indian J Sci Technol } 9 \text { (46): 1-12. DOI: } & \end{array}$ 10.17485/ijst/2016/v9i46/101551

Khaleghi MR 2017 The influence of deforestation and anthropogenic activities on runoff generation J For Sci 63 (6): 245-253. DOI: 10.17221/130/2016-JFS

Kathiresan K, Bingham BL. 2001. Biology of mangrove and mangrove ecosystem. Adv Mar Biol 40: 81-251

Khorimatun S, Takarina ND, Soedjiarti T. 2019. Community structure of plant-associated mangroves at Blanakan Fishpond Area, Subang,
West Java. In: Mart T, Triyono Dj, Ivandini T. (eds.). Proceedings of the 4th International Symposium on Current Progress in Mathematics and Sciences. Universitas Indonesia, Depok, 30-31 October 2018.

Linneweber V. 2002. Mangrove Ecosystems Function and Management. Lacerda LD de (ed.). Springer-Verlag, Berlin.

Long XX, Yang XE, Ni WZ, Ye ZQ, He ZL, Calvert DV, Stoffella JP. 2003. Assessing zinc thresholds for phytotoxicity and potential dietary toxicity in selected vegetable crops. Commun Soil Sci Plant Anal 34 (9\&1): 1421-1434. DOI: 10.1081/PFC-120015443.

Madera-Parra CA, Peña-Salamanca EJ, Peña MR, Rousseau DPL, Lens PNL. 2015. Phytoremediation of landfill leachate with Colocasia esculenta, Gynerum sagittatum and Heliconia psittacorum in constructed wetlands. Intl J Phytorem 17: 16-24. DOI: 10.1080/15226514.2013.828014

Naik N, Dhab A. 2018. Diversity of mangroves and mangrove associates from Purna Estuary, South Gujarat International J Adv Sci Res 3 (2): 157-162

Noor YZ, Khazali M, Suryadiputra IN. 1999. Panduan Pengenalan Mangrove di Indonesia. Wetlands Indonesia, Bogor. [Indonesian]

Ogundele DT, Adio AA, Oludele OE 2015. Heavy metal concentrations in plants and soil along heavy traffic roads in North Central Nigeria. J Environ Anal Toxicol 5: 334. DOI: 10.4172/2161-0525.1000334

Santos LCM, Matos HR, Schaeffer-Novelli Y, Cunha-Lignon M, Bitencourt MD, Koedam N, Dahdouh-Gebas F. 2014. Anthropogenic activities on mangrove areas (São Francisco River Estuary, Brazil Northeast): A GIS-based analysis of CBERS and SPOT images to aid in local management. Ocean Coast Manag 89: 39-50. DOI: 10.1016/j.ocecoaman.2013.12.010

Siarudin M, Rachman E. 2008. Biomassa lantai hutan dan jatuhan serasah di kawasan mangrove Blanakan, Subang, Jawa Barat. Jurnal Penelitian Hutan dan Konservasi Alam 5 (4): 329-335. [Indonesian]

Soraya R, Takarina N, Soedjiarti T. 2019. Metals accumulation (Cu, Zn and $\mathrm{Pb}$ ) in mangrove-associated plants from Blanakan brackish water Pond, Subang district, West Java. In: Mart T, Triyono Dj, Ivandini T. (eds.). Proceedings of the 4th International Symposium on Current Progress in Mathematics and Sciences. Universitas Indonesia, Depok, 30-31 October 2018.

Sukardjo S. 2004. Fisheries associated with mangrove ecosystem in Indonesia: a view from a mangrove ecologist. Biotropia 23: 13-39.

Takarina ND, Pin TG. 2017. Bioconcentration factor (BCF) and translocation factor (TF) of heavy metals in mangrove trees of Blanakan fish farm. Makara J Sci 21 (2): 77-81. DOI: 10.7454/mss.v21i2.7308

Winata A, Yuliana E, Hewindati YT, Rahadiati A.2017. Kekayaan flora dan karakteristik vegetasi mangrove hutan lindung pantai pulau Rimau, kabupaten Banyuasin, Sumatera Selatan. In Prosiding Seminar Nasional Tahunan Matematika, Sains dan Teknologi 2017. Universitas Terbuka Convention Center, 12 October 2017. [Indonesian] 